\title{
Natural Vulnerability Assessment to Contamination of Unconfined Aquifers by Longitudinal Conductance - (S) Method
}

\author{
Antonio Celso de Oliveira Braga ${ }^{1} \&$ Richard Fonseca Francisco ${ }^{1}$ \\ ${ }^{1}$ Department of Applied Geology, São Paulo State University, Rio Claro, Brazil \\ Correspondence: Antonio Celso de Oliveira Braga, Department of Applied Geology, São Paulo State University, \\ Rio Claro, Zip Code: 13.506-900, Brazil. Tel: 55-193-526-9290. E-mail: acobraga@rc.unesp.br
}

Received: July 13, 2014 Accepted: July 29, 2014 Online Published: November 9, 2014

doi:10.5539/jgg.v6n4p68 URL: http://dx.doi.org/10.5539/jgg.v6n4p68

\begin{abstract}
Given the importance of the groundwater for diverse uses, particularly the public supply, and considering the increasing impacts on underground reserves as a result of overexploitations, as well as the degradation of the water quality by anthropogenic activities, it becomes essential to establish tools for planning and management of the use of groundwater resources. For this reason, the aim this paper is to assess the natural vulnerability to contamination of the Bauru Aquifer System, in the South-Central region of the State of São Paulo, Brazil. Therefore, a vulnerability map was generated by using the (S) method, a new proposal developed to estimate the vulnerability by means of the Dar Zarrouk parameter - longitudinal conductance (electrical resistivity method). The vulnerability classes were defined using values ranges of longitudinal conductance: from very low $(>2.5$ siemens) to extreme $(<0.1$ siemens). In applying this methodology in the unsaturated zone, the electrical resistivity of the first layer of the saturated zone was used, seeing that the materials of both zones are similar in the study area. The application of the (S) method produced good outcomes, generating a more detailed map, with greater classes variability that indicate the sensitivity of this method, predominating regions with low vulnerability, and secondly, moderately vulnerable areas.
\end{abstract}

Keywords: groundwater, vulnerability, electrical resistivity, longitudinal conductance.

\section{Introduction}

The importance of studies about the natural vulnerability to contamination is unquestionable, as they provide support for decision-making relating to protection of groundwater resources. Moreover, the remediation of a site always tends to be difficult and impractical in several situations, from the standpoint financial, technical and operational. For this reason, it becomes imperative to establish tools for planning and management of the rational use of aquifers.

The natural vulnerability is a concept that expresses the sensitivity of an aquifer to be adversely affected by an imposed contaminant load (Van Waegeningh \& Van Duijvenbooden, 1987; Foster \& Hirata, 1988; Vrba \& Zaporozec, 1994). As a rule, the main parameters to be considered in the natural vulnerability assessment involve the confinement degree (confined to unconfined), depth to groundwater table and the lithology and consolidation level of the strata above the saturated zone. With regard to unconfined aquifers, the contaminants attenuation capacity and hydraulic accessibility of the unsaturated zone should be included in the vulnerability estimation (Foster \& Hirata, 1987).

Several methods have been developed and applied in the systematic process for assessing the vulnerability of groundwater to contamination. Each method has its advantages and limitations, and none can be considered the most appropriate for all situations (Foster, Hirata, Gomes, D'elia, \& Paris, 2002). Large part of the vulnerability assessment strategies have been outlined within the group of the indexers-parametric methods. This is due to lack of technical knowledge about how to mathematically formulate the processes, as well as restrictions regarding to availability and quality of the data, necessary conditions to statistical and deterministic methods (Qamhieh, 2006).

In indexers-parametric methods, each parameter displays a range relating to its property, subdivided into discrete and hierarchized intervals with specific values, which reflect their susceptibility level to contamination (Gogu \& Dassargues, 2000). Since the publication of the DRASTIC method (Aller, Bennett, Lehr, Petty, \& Hackett, 1987), 
several parametric-indexing methods have been developed to assess the natural vulnerability of aquifers, such as: GOD (Foster \& Hirata, 1988); AVI (Van Stempvoort, Ewert, \& Wassenaar, 1992); SINTACS (Civita, 1994), EPIK (Doerfliger \& Zwahlen, 1997); GALDIT (Chachad \& Lobo-Ferreira, 2001) and SAI method (Heredia \& Cirelli, 2007).

In general, indexers-parametric methods need to be quite flexible, with regard to the insertion of other parameters that also define the vulnerability of an aquifer, inclusively the integration ways between this new data, since each area has its specific characteristics. Therefore, the proposal of a new method or the adaptation of the existing ones should consider the needs of each area, as well as the data availability and the ease to acquisition them, in order to provide more reliable vulnerability maps.

Thus, the aim this paper is to assess the natural vulnerability to contamination by using the (S) method, a new proposal developed to estimate the vulnerability by means of the Dar Zarrouk parameter - longitudinal conductance (method of resistivity), parameter originally described by Maillet (1947).

\subsection{Study Area}

The study area refers to Bauru Aquifer System, located in the South-Central region of the State of São Paulo, Brazil. It has approximately $7086 \mathrm{~km}^{2}$, whose major access routes are the state highways President Castelo Branco (SP - 280) and Marechal Rondon (SP - 300), according to Figure 1.

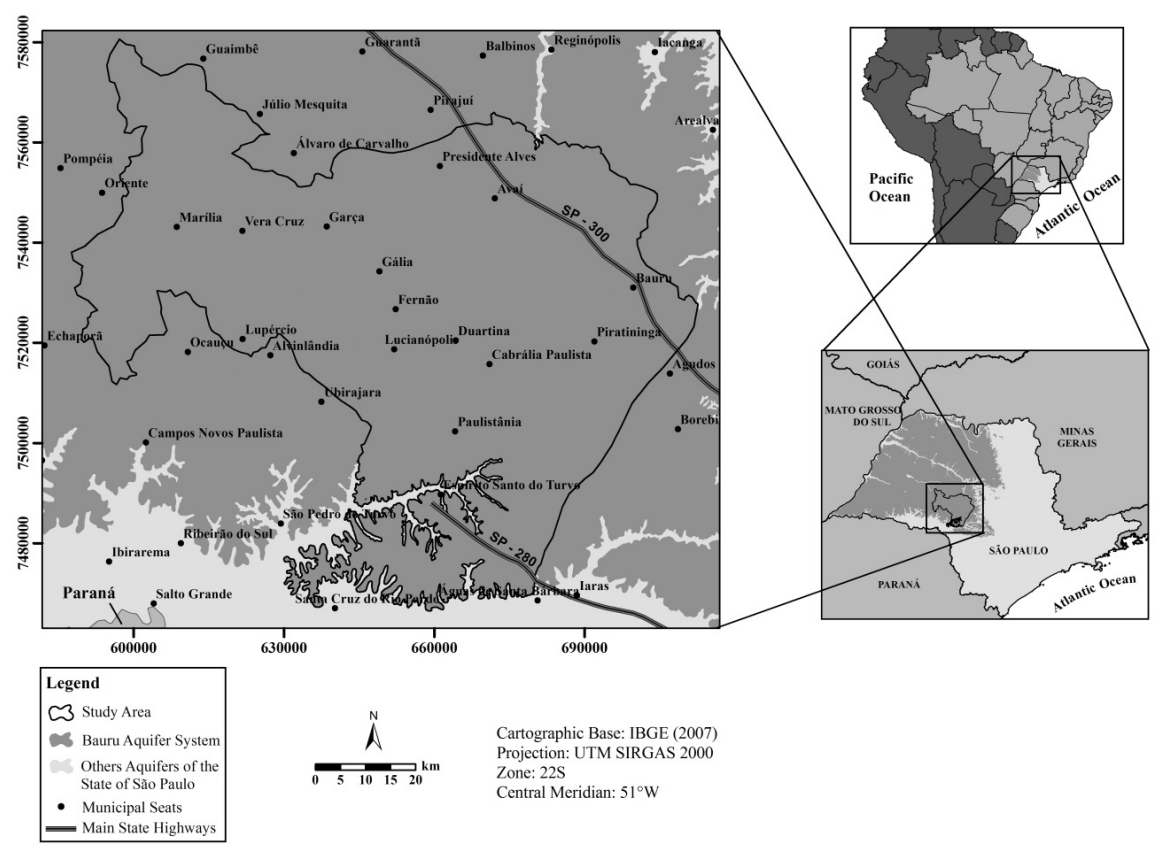

Figure 1. Location of the study area in the Bauru Aquifer System

In the study area, the participation degree of groundwater in the public supply is high, whereas some municipalities are totally dependent on this aquifer system due to impairment of the quantity and quality of surface waters, such as Águas de Santa Bárbara, Gália, Piratininga, Espírito Santo do Turvo, Alvinlândia and Lucianópolis (Cetesb, 2012a, 2012b).

Even though the incidence of declared areas as contaminated in the Bauru Aquifer System be low, in general, have been reported contamination records. In fact, this is owing to nitrate concentrations that exceed the potability standard for human consumption, which is $10 \mathrm{mg} \cdot \mathrm{L}^{-1} \mathrm{~N}-\mathrm{NO}^{3-}$, threshold established by Ordinance $\mathrm{N}^{\mathrm{o}} 2$ 914 of the Health Ministry (Brazil, 2011).

Proceeding from domestic sewage and of the inappropriate use of fertilizers in the cultivation of sugarcane, the excessive nitrate was detected in several deep tubular wells and small water holes, located in urban and rural zones of many counties of the west of the State of São Paulo, as Bauru, Presidente Prudente, São José do Rio Preto, Fernandópolis and Votuporanga (Ezaki, Fernandes, Ferreira, \& Iritani, 2011).

Recently, some studies have shown that high nitrate concentrations in groundwater have been frequent in urban areas of several municipalities of the State of São Paulo, including large urban centers contained in the study 
area, as Bauru and Marilia. Important results can be found in Varnier, Iritani, Viotti, Oda and Ferreira (2010), Barbour et al. (2010), Giafferis and Oliveira (2006).

Until the present moment, the researches about the natural vulnerability of the Bauru Aquifer System are scarces, even though already it is recognized its importance for the supply of a set of municipalities with thousands of consumers. Furthermore, the main existing research was developed and presented in scale with little detail (IG, CETESB, \& DAEE, 1997), restricting the application in the planning and managing of the use of the groundwater resources at the municipal level. Therefore, it is recommended the development of further detailed works, which result in more reliable and accurate vulnerability maps, with costs and deadlines appropriates to the possibilities of the communities.

\subsection{Geological and Hydrogeological Contexts}

Regarding the regional geological context, the Bauru Group is located in Paulista Western Plateau, totaling an area of $117000 \mathrm{~km}^{2}$, which corresponds to approximately 47\% of state territory (DAEE, 1990). The Bauru Group rocks consist predominantly of clayey sandstones, carbonated or not, siltstones, mudstones and shales, conglomerates and occasionally present calcareous layers (DAEE, 1976).

In the study area, the Adamantina and Marilia formations are predominant, representing $99.65 \%$ of the total surface (Figure 2). Locally, alluvial deposits restricted to the plains of major streams are found. Secondly, there is the occurrence of small outcrops of Pirambóia and Corumbataí formations (DAEE, SMA, \& UNESP, 1984).

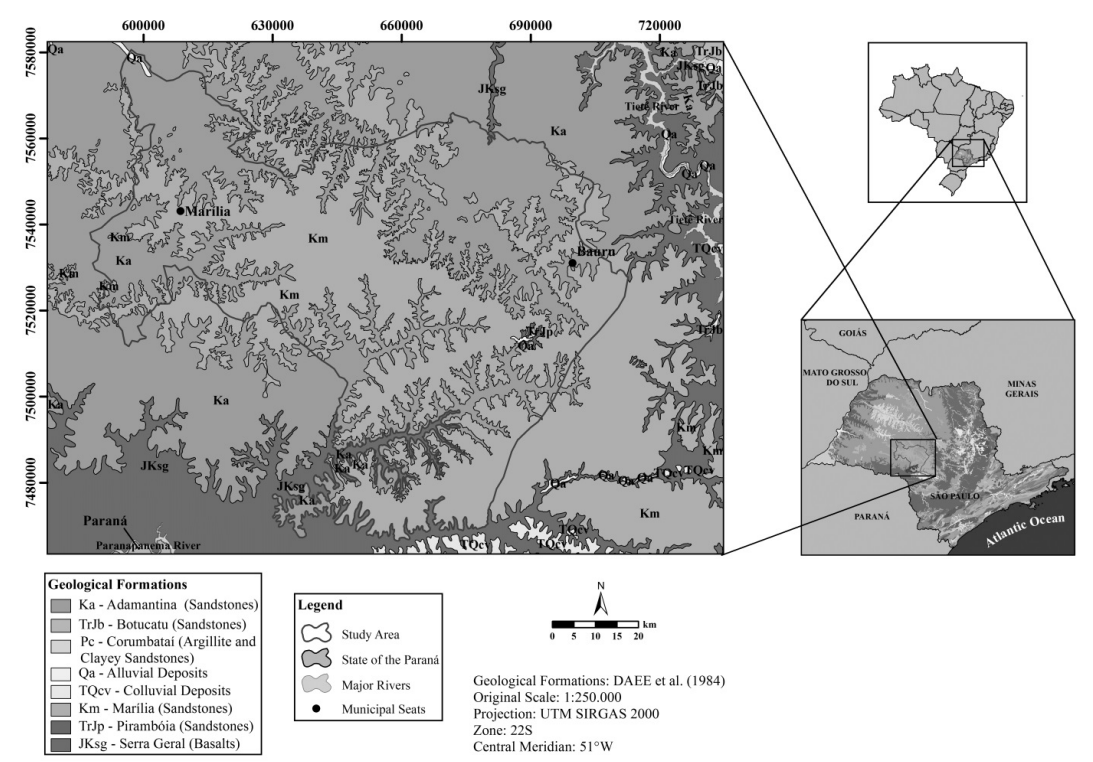

Figure 2. Geological formations map

The Bauru Aquifer System is a hydrogeological unit with regional extension, continuous surface, unconfined to semi-confined and mean thickness equal to 100 meters, however, may exceed 300 meters. This system is considered moderately permeable, due to the clay-silty-carbonatic cement content is relatively high and intercalations between permeable and impermeable layers (Figure 3) (DAEE, 1976, 1979).

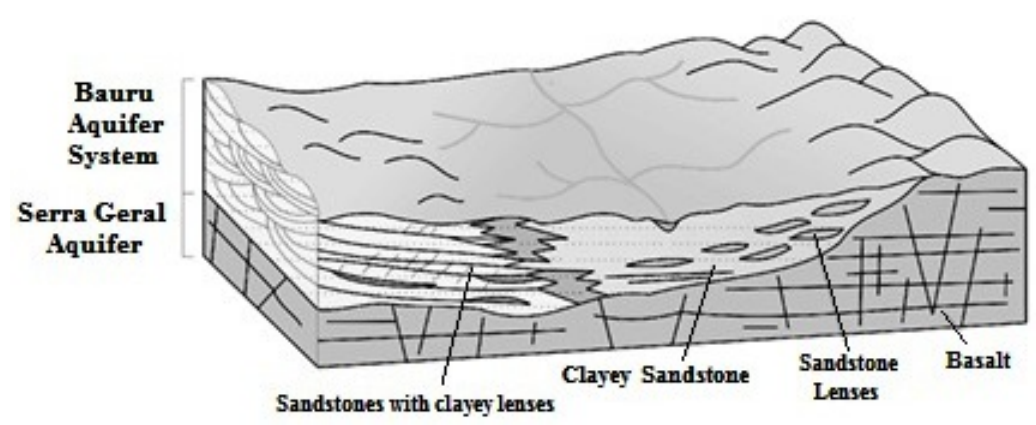

Figure 3. Conceptual hydrogeological model of the Bauru Aquifer System 
According to Barcha (1980), percentages of silt and clay above $10 \%$ is sufficient to reduce the permeability of the rocks in the study area, making them impermeable from the practical point of view. Similarly, the carbonatic cement exerts an influence on the permeability, since concentrations greater than $10 \%$ may represent an effective barrier to the water movement.

Based on hydrostratigraphic division of the Bauru Aquifer System proposed by Paula and Silva (2005), the Marília and Adamantina aquifers occur in the study area. The Marilia aquifer is represented by a fairly homogeneous succession, predominantly sandy, granulometry fine to coarse, low clay content, thin intercalations between pelitic materials and carbonate zones. This aquifer has quite unfavorable hydrodynamic characteristics due to excessive cementation by carbonates, which became its sediments practically impermeable. The Adamantina aquifer is heterogeneous, and like the Marília aquifer, it presents carbonatic cementation in the sediments, however, with less intensity. Therefore, in this aquifer the sediments with moderate permeability and anisotropic water flow are predominant. These characteristics result, primarily, from changes in the permeability of the sediments, arising to the higher or lower clay content of the matrix, or pelitic layers that are interspersed with sandy materials.

\section{Methods}

\subsection{Data Acquisition}

Electrical resistivity measurements using the vertical electrical sounding (VES) technique - Schlumberger array were used in the survey area. To cover in a uniform way the study area, 106 (one hundred and six) VES were used (Figure 4), geophysical surveys conducted by the Institute for Technological Research of the State of São Paulo (IPT, 1977, 1978, 1980a, 1980b, 1981). The Schlumberger array allowed the reach from medium to large depths (between 500 and 10000 meters of theoretical research). This is due to the objectives of these VES, which focused on the very great depths investigation, in order to reach the top of the basalt rocks and study the lithostratigraphy of the Guarani Aquifer System, including the prospecting for oil and natural gas on the Paraná river basin.

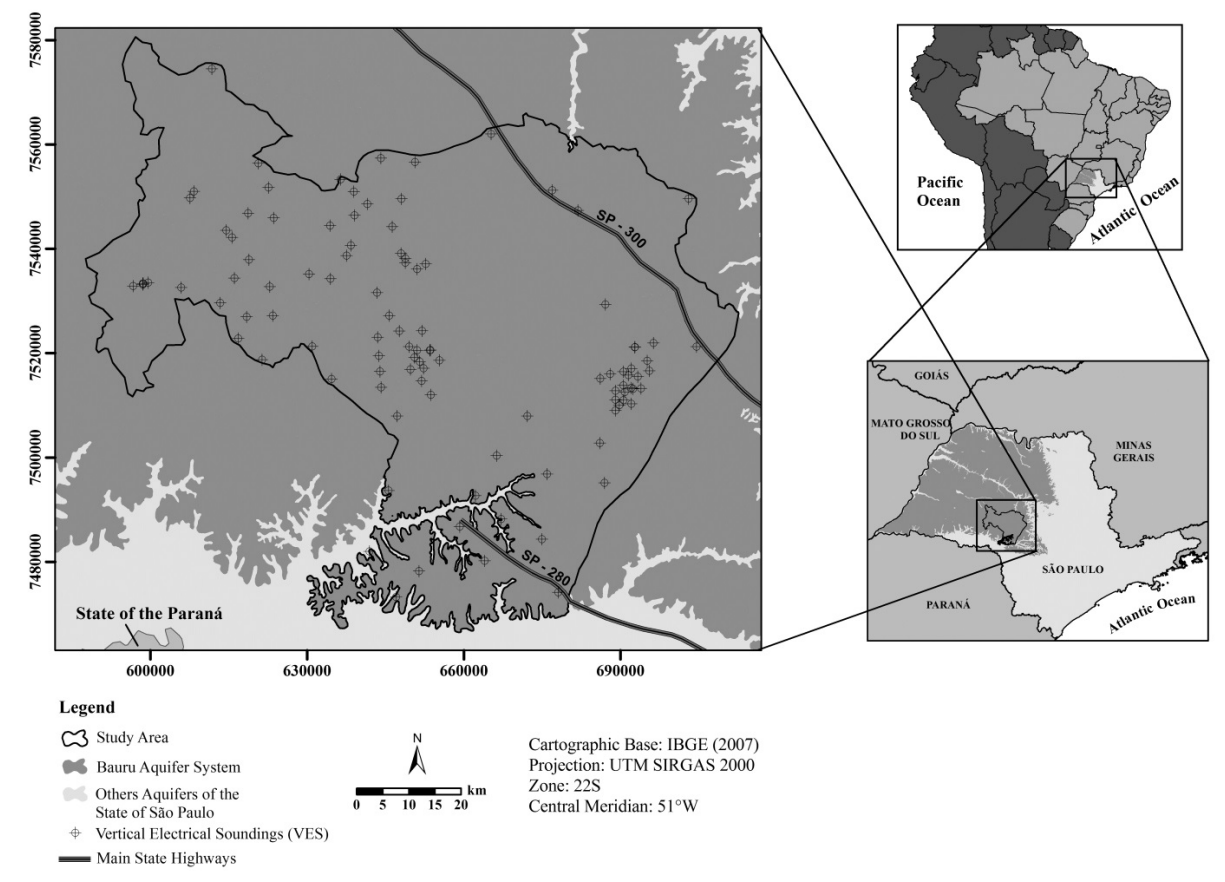

Figure 4. Location of the VES in the study area

\subsection{The Electrical Resistivity Method and the Vertical Electrical Sounding Technique}

From Ohm's Law, where $(\Delta V)$ presents the voltage variation and $(I)$ is the electric current, which considers the spacing between the electrodes, represented by a factor called $K$, it obtains the apparent resistivity parameter $\left(\rho_{a}\right)$ of the materials for various depths (Equation 1).

$$
\rho_{\mathrm{a}}=\mathrm{k} \cdot \frac{\Delta \mathrm{V}}{\mathrm{I}}
$$


The electrical resistivity method is based on parameter determination that relate to the electric current flow, both natural power sources (e.g., electrochemical processes) such as artificial sources coming from batteries and generators, which feed a current transmitting unit may be used (Kearey, Brooks, \& Hill, 2002). In this method, the electric current is introduced into the soil by means of an electrodic device, generally composed of four electrodes. The electrodes A and B are used for the current application in the subsurface, connecting to an amperemeter (A) whereby electrical cables. The electrodes $\mathrm{M}$ and $\mathrm{N}$ are agreed as potential electrodes, used to measure the potential difference generated by the electrical circuit (Figure 5). This circuit is connected to a voltmeter (V) to measure the potential difference between them (Telford, Geldart, \& Sheriff, 2004).

The vertical electrical sounding (VES) technique - Schlumberger array - is a very agile and versatile procedure to geophysical survey (Figure 6). In field, this array is considered the most practical devices, as there is only the symmetric displacement between the current electrodes A and B, with respect to the central point "O" of the geophysical survey, while the electrodes $\mathrm{M}$ and $\mathrm{N}$ remain fixed. Thus, the measures are less subject to interferences, minimizing the susceptibility to misinterpretations in heterogeneous lithologies. For this reason, the registered error in this arrangement kind is negligible, based on the general equations needed to the basic adjustments (Orellana, 1972). The same author suggests a relationship between the current electrodes and potential equal to $\mathrm{MN} \leq \mathrm{AB} / 5$.

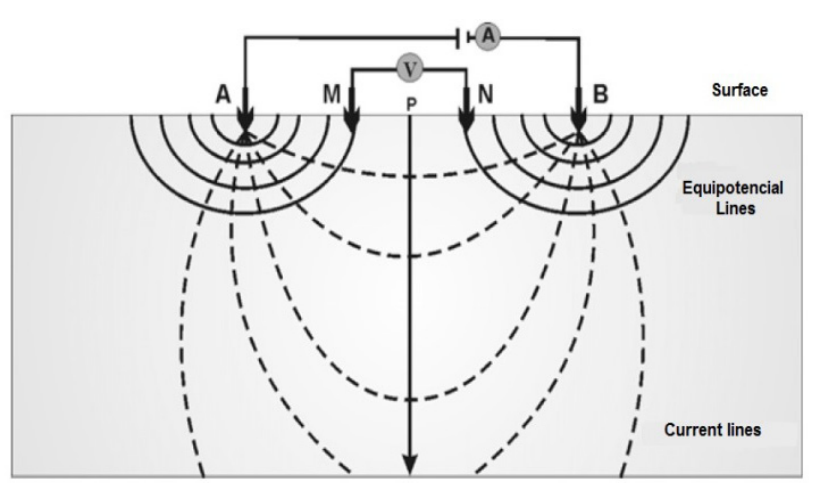

Figure 5. Array for resistivity measurements

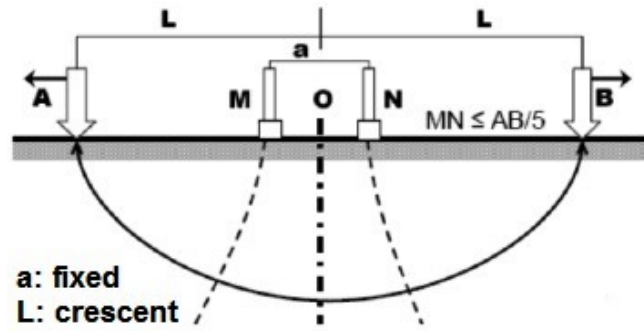

Figure 6. VES Technique - Schlumberger array

According to Braga (2008), the electrical resistivity reflects some of the major characteristics of material different types in the geological environment, allowing the estimation of their states, regarding to the alteration, fracturing and water saturation degree. Besides, it is possible to identify the lithologies without the need for excavation or perforations, which are commonly costly and time consuming. Additionally, the author points out that the resistivity method (direct current) and the VES - Schlumberger array - offer products extremely important to preliminary steps of environmental studies, as the electrical resistivity, the depth of the groundwater level and the Dar Zarrouk parameter Longitudinal Conductance.

\subsection{Dar Zarrouk Parameter - Longitudinal Conductance}

The resistivity method can be applied to establish relations between electrical resistivity and hydrogeological parameters, such as porosity, permeability, transmissivity and hydraulic conductivity. This way, the correlations are grounded in existing analogies between equations that govern the groundwater flow through a permeable medium and the electric current in a conductive medium. Starting at geoelectric measurements taken at the surface, hydrodynamic characteristics of an aquifer can be estimated (Porsani, Carlos, Elis, \& Prado, 2012).

These relations can be established using the Dar Zarrouk parameters, obtained by the division and multiplication operations between the resistivities and thicknesses of each layer of the geoelectrical model (Maillet, 1947). For a sequence of $n$ horizontal, homogeneous and isotropic layers with resistivity $\rho_{i}$ and thickness $h_{i}$, the Dar Zarrouk parameter Longitudinal Conductance (S) unitary and total, respectively, are defined according to Equations 2 and 3:

$$
\begin{aligned}
& \mathrm{S}_{\mathrm{i}}=\frac{\mathrm{h}_{\mathrm{i}}}{\rho_{\mathrm{i}}} \quad \text { (siemens) } \\
& \mathrm{S}=\sum_{\mathrm{i}-1 \frac{\mathrm{n}}{\rho_{\mathrm{i}}}}^{\mathrm{h}} \quad \text { (siemens) }
\end{aligned}
$$




\subsection{The Longitudinal Conductance Method - (S)}

In granular and unconfined aquifers, the main natural protection against the contamination is related to the presence of overlapping clay layers, whose protection capability comes down to the infiltration time lag of solutions, due to their low permeability. Henriet (1975) demonstrated that the protection degree of an aquifer may be considered directly proportional to the ratio between the thickness and resistivity, or in other words, the Longitudinal Conductance (S), which it enables to define the protection degree of groundwater front of contaminants migrating vertically. However, it was necessary to modify the term "degree of protection" for "vulnerability", in order to fit this new method to the terminology used by those already existing.

In this manner, a overlying layer with high longitudinal conductance (generally greater than 1.0) offers a high protection degree to contamination, therefore the bigger the thickness of this layer, the greater the infiltration time of the contaminants (large filter) and the lower the resistivity, the more clayey and less permeable the material will be (Braga, Dourado, \& Malagutti Filho, 2006).

To establish the vulnerability classes of the (S) method (Table 1), which correspond to the values ranges of longitudinal conductance, it sought relationships between thickness and resistivity that could be considered representative of each class, in terms of hydraulic accessibility to the saturated zone and pollutant attenuation capacity of the unsaturated zone.

Table 1. Relations between the geoelectric parameters and the vulnerability classes of the (S) Method

\begin{tabular}{cccc}
\hline $\begin{array}{c}\text { Vulnerability } \\
\text { Classes }\end{array}$ & $\begin{array}{c}\text { Geoelectrical Model Parameters } \\
\text { Resistivity } \\
\text { (ohm.m) }\end{array}$ & $\begin{array}{c}\text { Thickness } \\
\text { (meters) }\end{array}$ & $\begin{array}{c}\text { Dar Zarrouk Parameter } \\
\text { Longitudinal Conductance (S) } \\
\text { (siemens) }\end{array}$ \\
\hline Very Low & $<10$ & $>25$ & $>2.5$ \\
Low & 10 a 20 & 25 a 13 & 0.7 a 2.5 \\
Moderate & 20 a 40 & 13 a 10 & 0.3 a 0.7 \\
High & 40 a 100 & 10 a 5 & 0.1 a 0.3 \\
Extreme & 100 a 300 & $<5$ & $<0.1$ \\
\hline
\end{tabular}

\subsection{Generation and Integration of the Thematic Maps}

In order to produce the natural vulnerability map to contamination, thematic maps were generated for each of the two parameters of the (S) method. From the algebraic division between these maps and their reclassification, according previously established intervals for the values of the longitudinal conductance, obtained it the natural vulnerability map for the study area. Thus, the methodological procedures described as per follows were adopted.

\subsubsection{Thickness of the Unsaturated Zone $\left(\mathrm{h}_{\mathrm{i}}\right)$}

The thematic map related to the thicknesses of the unsaturated zone was obtained based on the interpretation of the vertical electrical sounding set. With a view to estimate the isovalue surface related to the thickness of the unsaturated zone, regarding the available information in each SEV, the Minimum Curvature interpolation method was used, whereby the Surfer 8.0 (Golden Software Inc., 2002).

The Minimum Curvature is a deterministic method widely used in the earth sciences, whose resulting surface is smoothed and resembles a thin, linear and elastic layer, going through each of the observed values. This method is not an exact interpolator and, therefore, the data are not always respected in their real values, which may be generated over the maximum limit or below the minimum (Andriotti, 2009; Landim, 2000). Overall, the results obtained from the use of this interpolator supply the aims of this survey, which is preliminarily assess the vulnerability on a regional work scale, seeking to highlight the trends in the study area.

\subsubsection{Electrical Resistivity $\left(\rho_{\mathrm{l}}\right)$}

Starting from the electrical resistivity, it is only possible to identify the different types of existing materials in the saturated zone. When it comes to the unconfined aquifers, the resistivities of the unsaturated zone are atypical, being inserted into a wide variation range. So, it is not possible to directly identify the materials of the unsaturated horizon, on lithological terms. However, the resistivity values obtained for the first layer of the saturated zone may be extrapolated to the overlapped sediments, provides that there is similarity between the materials of both zones (Braga, 2008). Therefore, it adopted this procedure to obtain the resistivity values of the 
unsaturated zone, since this assumption is valid for the survey area. Thus, an isovalue map for the electrical resistivity was developed, using the Surfer 8.0.

After obtaining the thematic maps for the two parameters of the (S) method, the ratio between them was conducted as Equation 2, through the Raster Calculator tool, Spatial Analyst Tools module, in the ArcGIS 10.0 (ESRI, 2010). Then, the obtained map was reclassified according to conductance longitudinal intervals, from the Reclassify tool Spatial Analyst Tools module, in the ArcGIS 10.0, resulting in the final vulnerability map.

\section{Results and Discussions}

\subsection{Electrical Resistivity and Thickness of the Unsaturated Zone}

The electrical resistivity of the unsaturated zone ranged between $8.0 \Omega . \mathrm{m}$ and $70.0 \Omega . \mathrm{m}$, with mean value and standard deviation equal to $30.2 \Omega . \mathrm{m}$ and $12.7 \Omega . \mathrm{m}$, respectively. According to the histogram (Figure 7), the most frequent values are at the center of the distribution, in the range between $22 \Omega . \mathrm{m}$ and $42 \Omega . \mathrm{m}$, indicating geoelectrical behavior predominantly correlated to sandy-clay materials in the study area.

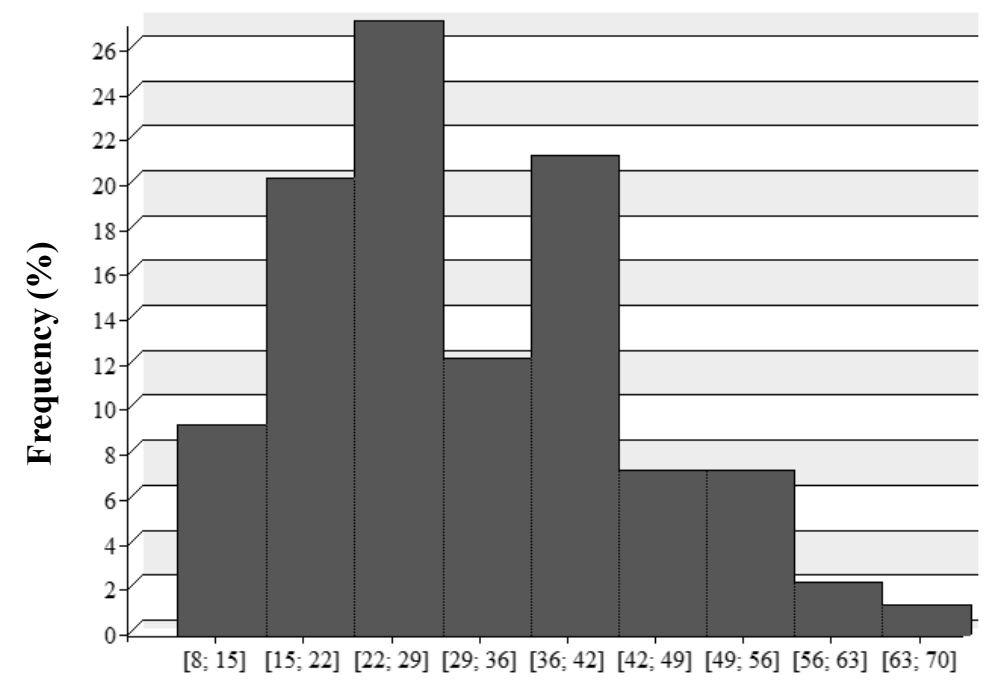

Electrical Resistivity (ohm.m)

Figure 7. Histogram of the distribution of resistivity values of the unsaturated zone

As a rule, the lower the resistivity, the more clayey are the materials of the saturated zone. The lowest electrical resistivities are situated mainly in the fields of the formations Adamantina and Corumbataí, in which there is a predominance of argillaceous sandstones and silty materials.

Areas with a little higher electrical resistivity are located within the limits of the Marilia Formation, which presents clay content slightly lower than that seen in Adamantina Formation. In general, the Pirambóia Formation and the small fragments of alluvial deposits also showed electrical resistivity values higher than those recorded for Adamantina Formation, due to its composition predominantly sandy.

Within the geographical boundaries of a sedimentary geological formation, there may be a certain lithological diversity in some locations as paleoenvironmental variations at the deposition time of the units, tending to occur more frequently in those that fill large areas, such as of the Adamantina and Marilia formations. For this reason, the boundaries of the resistivity classes shown in Figure 8 do not correspond exactly to the limits of those geological formations, owing to the heterogeneity of the existing materials and spatial distribution of the interpolated data. 


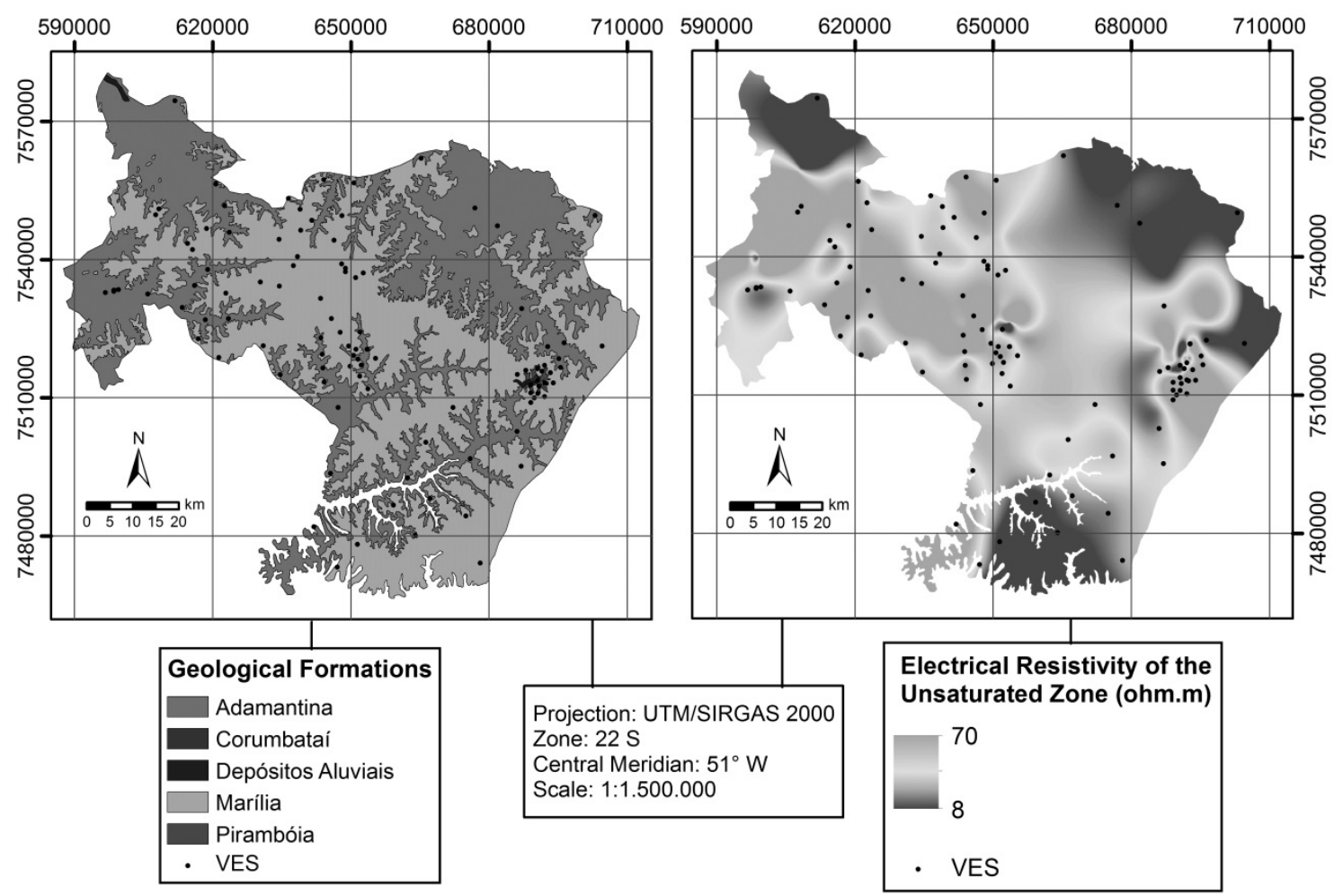

Figure 8 . Relations between the electrical resistivity and lithology in the survey area

The thickness of the unsaturated zone (depths of groundwater level) ranged between 2.5 and 51 meters, with mean equal to 15.41 meters. It is noteworthy that there was a predominance of thickness in the range between 20 and 50 meters) and, secondly, between 10 and 20 meters. Thicknesses greater than 50 meters occur in the south and east extremes of the study area, according to Figure 9.

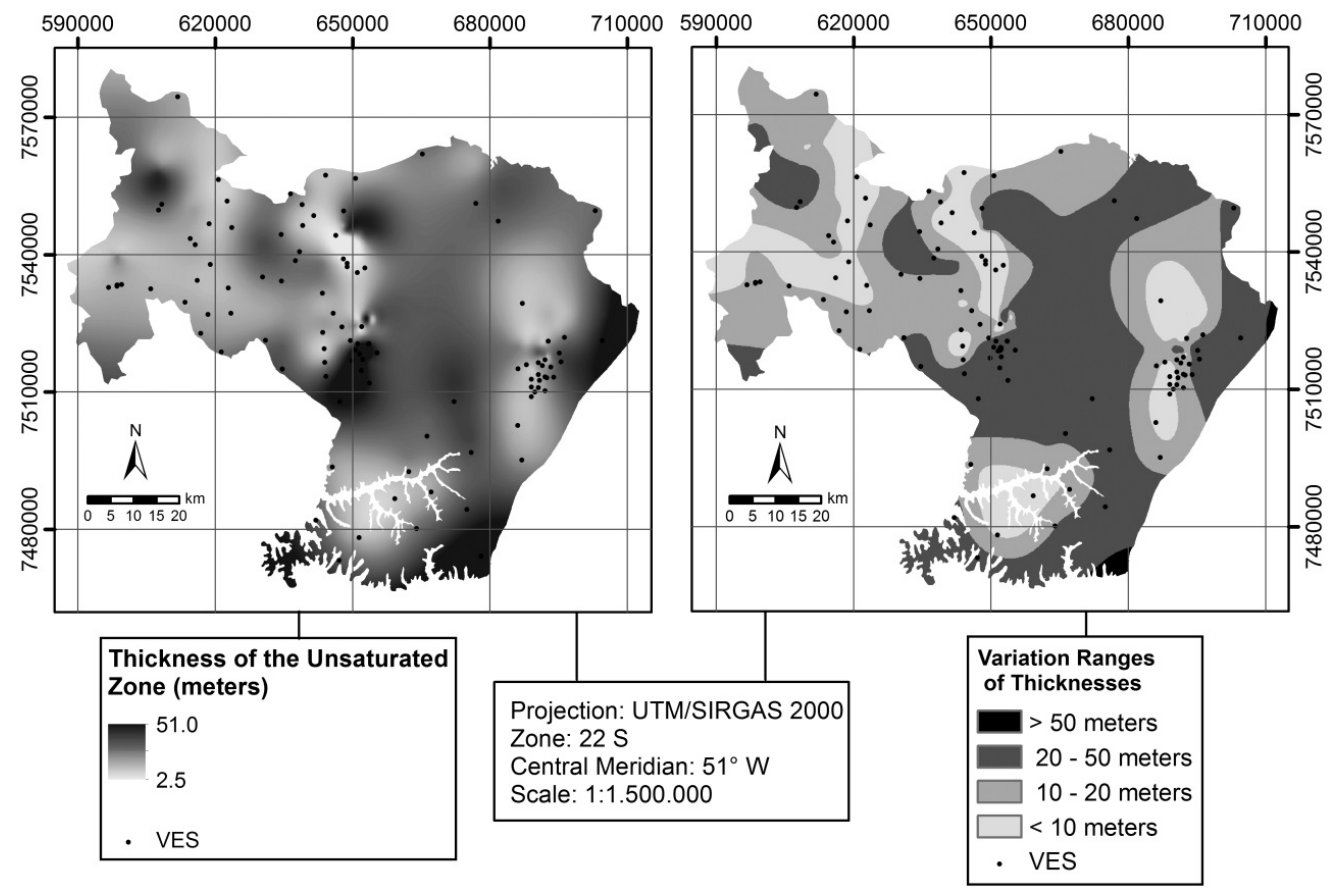

Figure 9. Thicknesses of the unsaturated zone 


\subsection{Natural Vulnerability Mapping by Longitudinal Conductance Method - (S)}

From the division operation between the thickness and electrical resistivity maps, a more heterogeneous and detailed vulnerability map was obtained, whose class distribution was more balanced in the survey area, as per Figure 10.

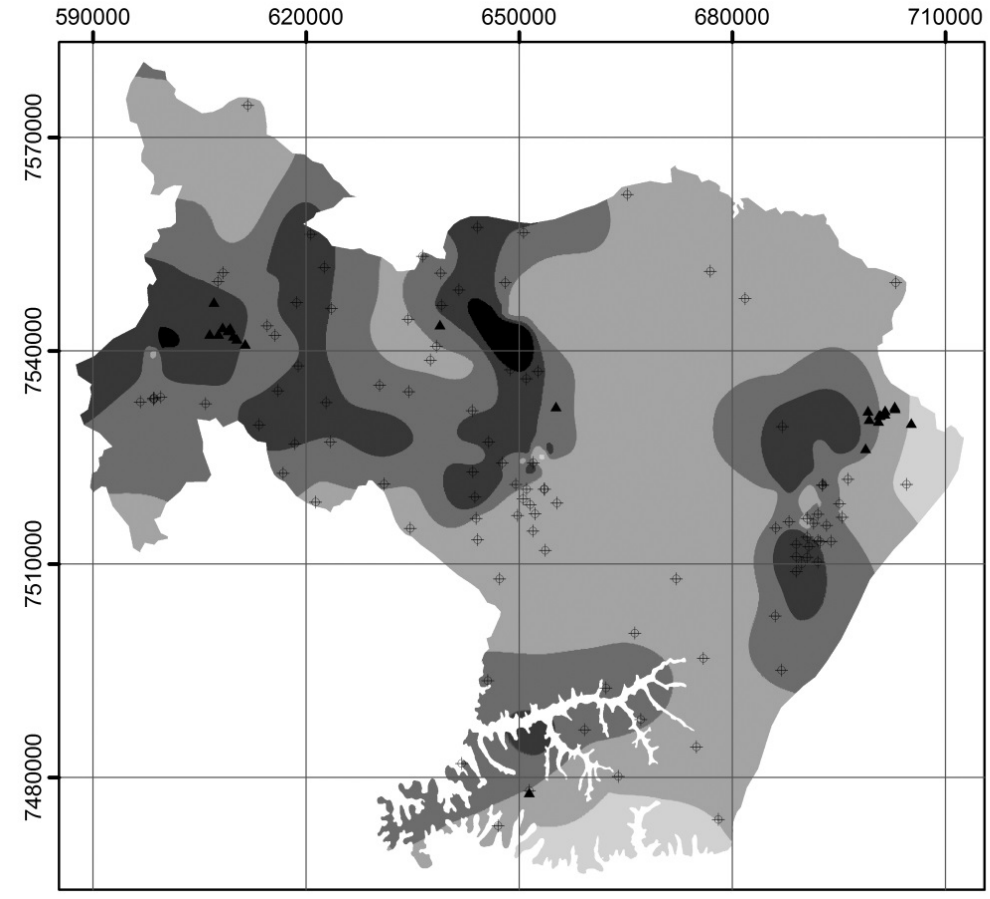

Vulnerability Classes -

\section{(S) Method}

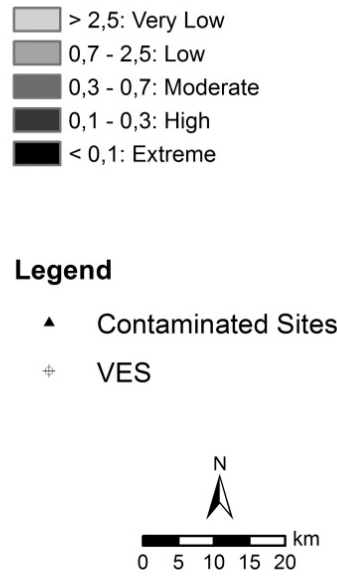

Contaminad Sites: CETESB (2011) Projection: UTM/SIRGAS 2000

Zone: $22 \mathrm{~S}$

Central Meridian: $51^{\circ} \mathrm{W}$

Scale: 1:1.000.000

Figure 10. Vulnerability map resulting from the application of the (S) method

In approximately $50 \%$ of the area, there was a predominance of regions with low vulnerability and, secondarily, moderate vulnerability areas, representing $30.6 \%$ of the total surface (Table 2). High and extremely vulnerable areas were detected, which together account for about $16 \%$ of the study area, in places with predominance of permeable sandy materials and smaller thickness of the unsaturated zone. Furthermore, the (S) method application indicated the existence of areas with very low vulnerability (3.83\%), located in the east and south ends, where there is a transition to the fractured aquifer Serra Geral.

Table 2. Vulnerability classes obtained by (S) method and the total area

\begin{tabular}{ccc}
\hline $\begin{array}{c}\text { Vulnerability } \\
\text { Classes }\end{array}$ & $\begin{array}{c}\text { Area } \\
\left.\mathbf{( k m}^{2}\right)\end{array}$ & (\%) \\
\hline Very Low & 271.46 & 3.83 \\
\hline Low & 3526.81 & 49.77 \\
\hline Moderate & 2168.24 & 30.60 \\
\hline High & 1063.03 & 15.00 \\
\hline Very High & 56.46 & 0.8 \\
\hline SUM & $\mathbf{7 0 8 6 . 0 0}$ & $\mathbf{1 0 0}$ \\
\hline
\end{tabular}

Regarding the contaminated sites (Cetesb, 2011), 70\% of the total are located in areas with moderate and high vulnerability, and of this percentage, $60 \%$ are located in places classified as highly vulnerable, which can be considered a indicative of the sensitivity of the (S) method. Is worth mentioning that most of contaminated sites result from the fuel station activities, developed in the municipalities with greater regional prominence as Bauru and Marília.

Based on the heterogeneity and distribution of the classes and, especially, the expected results as the geological and hydrogeological characteristics, the (S) method can be considered suitable for assessing the vulnerability of the study area, as long as the necessary data are available, especially the electrical resistivity of the materials. 
First of all, such a conclusion must be founded on the fact that the (S) method does not evaluate the vulnerability by assigning indexes to geological formations, which are highly heterogeneous features. Instead, this method considers the vulnerability of the lithology by means of the measurable parameter estimation, such as the thickness and electrical resistivity of the unsaturated layers, thereby reducing the subjectivity. The lack of this factor can be mentioned as one of the limitations of most evaluation methods already established, in which the coverage layers are always considered homogeneous throughout the length that occupy, at the assignment time of the indexes, which result from a subjective comparison between the lithologies.

Besides, in the $(\mathrm{S})$ method the ranges of the longitudinal conductance values are discrete, whose determination proceeded from the ratios between thicknesses and resistivities. Therefore, the resulting vulnerability map is less generalist and more detailed, offering a greater variability in classes.

One of the advantages of the (S) method is the greater detail degree of the vulnerability map and the minimization of subjectivity (conditioned to sampling grid), from only two input parameters, something very interesting considering the scarcity scenario of available data in several regions of the Brazil. In addition, this method can be very flexible as to the insertion of new parameters, for example, land slope, rainfall and structural geology data, especially the occurrence of faults and fractures that may provide preferential pathways to contamination.

The utilization of data coming from VES may represent others advantages, such as low cost for the rapid and accurate assessment of large areas; versatility in terms of investigation depth, without changing the conditions of the involved materials; and the availability of advanced programs for the data processing.

Nevertheless, the uncertainties inherent in processing such data can be reduced, if reliable geological and hydrogeological data are considered in the interpretation of the initial geoelectrical model, being possible to acquire them in previous studies or from descriptive profiles of preexisting wells.

\section{Conclusions}

Undoubtedly, it is expressive the contribution of groundwater for public supply of the municipalities belonging to the study area. Moreover, there is the growing endangering of the groundwater quality by high nitrate concentrations, as well as the existence of contaminated sites, even though incipient way. Therefore, works focusing on natural vulnerability assessment of the Aquifer System Bauru are fundamental, in so far allow to estimate more sensitive areas to pollution, and thus plan the installation and operation of projects with high degradation potential of the groundwater.

Thereby, surveys performed by the electrical resistivity method (direct current), vertical electrical sounding technique, obtaining the resistivity, thickness and Dar Zarrouk parameters, the different geological layers, allow to extract a lot of information, which can support studies involving the monitoring and protection of aquifers front of several contaminants. The (S) method application to assess the natural vulnerability of unconfined aquifers demonstrates to be quite promising in planning and management of the groundwater resources, mainly in studies of regional and municipal scale.

\section{Acknowledgements}

The authors would like to thanks the Department of Applied Geology - IGCE/Unesp, the IPT (Institute for Technological Research of the State of São Paulo) for the given data and the CAPES (Coordination of Improvement of Higher Education Personnel) for the financial support.

\section{References}

Aller, L., Bennett, T., Hackett, G., Lehr, J. H., \& Petty, R. J. (1987). Drastic: a standardized system for evaluating groundwater pollution potential hydrogeologic setting. Environmental Protection Agency (EPA), Report 600/2-87-035.

Andriotti, J. L. S. (2009). Fundamentals of statistical and geostatistical (2nd ed.). São Leopoldo: Unisinos.

Barbour, E. D. A., De Camargo, G. G., Do Vale, F. R. C., Lemos, M. M. G., Modesto, R. P., Moreno, F. N., ... Toffoli, F. F. (2010). Nitrate concentrations in the aquifer Bauru'waters - State of São Paulo. Paper presented at the Sixteenth Brazilian Congress of Groundwater and Seventeenth National Meeting of Well Drillers, São Luís, Maranhão, Brazil. Abstract retrieved from http://aguassubterraneas.abas.org/asubterraneas/article/view/23186

Barcha, S. F. (1980). Geological aspects and hydrogeological provinces of the Bauru Formation in north-western region of the State of São Paulo (Unpublished doctoral dissertation). UNESP - São Paulo State University, São José do Rio Preto, Brazil. 
Braga, A. C. O., Dourado, J. C., \& Malagutti Filho, W. (2006). Resistivity (DC) method applied to aquifer protection studies. Brazilian Journal of Geophysics, 24(4), 573-581.

Braga, A. C. O. (2008). Estimation of the natural vulnerability of aquifers: a contribution from the resistivity and longitudinal conductance. Brazilian Journal of Geophysics, 26(1), 61-68.

Brazil. Health Ministry. (2011). Ordinance n. 2 914. Refers to the procedures for control and monitoring of water quality for human consumption and its potability standards. Federal Official Gazette: Federative Republic of the Brazil, Executive Power, Brasilia, Brazil, 239(148), Section 1, 39-46. Retrieved May 3, 2014, from http://www.in.gov.br/visualiza/index.jsp?data=14/12/2011 \&jornal $=1$ \&pagina $=39 \&$ total $A$ rquivos $=192$

CETESB - Environmental Company of the State of São Paulo (2011). Explicative Text: list of contaminated and rehabilitated sites in the State of São Paulo. Retrieved April 10, 2014, from http://www.cetesb.sp.gov.br/userfiles/file/areas-contaminadas/2011/municipios.pdf

CETESB - Environmental Company of the State of São Paulo (2012a). Groundwater quality in the state of São Paulo in the period between 2010 and 2012. São Paulo, SP: CETESB.

CETESB - Environmental Company of the State of São Paulo (2012b). Surface waters quality in the State of São Paulo. São Paulo, SP: CETESB.

Chachadi, A. G., \& Lobo-Ferreira, J. P. (2001). Sea water intrusion vulnerability mapping of aquifers using GALDIT method. Paper presented at the Proc. Workshop on Modelling in Hydrogeology, Chennai, Tamil Nadu, India.

Civita, M. (1994). The vulnerability maps to pollution of groundwater: Theory and practice. Bologna: Pitagora.

DAEE - Department of Water and Electric Energy of the State of São Paulo (1976). Study groundwater in the administrative regions 7, 8 and 9 - Bauru, São José do Rio Preto and Araçatuba. São Paulo: DAEE.

DAEE - Department of Water and Electric Energy of the State of São Paulo (1979). Study groundwater in the administrative regions 10 and 11 - Presidente Prudente e Marília. São Paulo: DAEE.

DAEE - Department of Water and Electric Energy of the State of São Paulo, UNESP - São Paulo State University, \& SMA - Department of the Environment of the State of São Paulo (1984). Geological Map of the State of São Paulo on Scale 1:250.000. São Paulo: DAEE, UNESP, SMA.

DAEE - Department of Water and Electric Energy of the State of São Paulo (1990). State plan to water resources. São Paulo: DAEE.

Doerfliger, N., \& Zwahlen, F. (1997). EPIK: a new method for outlining of protection areas in karstic environment. Paper presented at the International Symposium on Karst Waters and Environmental Impacts, Antalya, Turkey. Balkema, Rotterdam.

ESRI - Environmental Systems Research Institute. (2010). ArcGIS Professional GIS for the Desktop, version 10.0. ESRI.

Foster, S. S. D., \& Hirata, R. C. A. (1987). Groundwater contamination. Lima: WHO/PAHO/HPE/CEPI.

Foster, S. S. D., \& Hirata, R. C. A. (1988). Groundwater pollution risk evaluation: the methodology using available data. Lima: WHO/PAHO/HPE/CEPI.

Foster, S. S. D., Hirata, R. C. A., Gomes, D., D'elia, M., \& Paris, M. (2002). Quality protection groundwater: guide for water service companies, municipal authorities and environment agencies. Washington, DC: World Bank. http://dx.doi.org/10.1596/0-8213-4951-1

Giafferis, G. P., \& Oliveira, E. L. (2006). Investigation of the groundwater quality in the city of Bauru, Proceedings of the 14th Brazilian Congress of Groundwater, Curitiba, Paraná, Brazil.

Gogu, R. C., \& Dassargues, A. (2000). Current and future trends in groundwater vulnerability assessment. Environmental Geology, 39(6), 549-559. http://dx.doi.org/10.1007/s002540050466

Golden Software Inc. (2002). Surfer 8: User's guide/contouring and 3D surface mapping for scientists and engineers, version, 8 , Golden Software Inc.

Henriet, J. P. (1975). Direct applications of the Dar Zarrouk parameters in ground water surveys. Geophysical Prospecting, 24, 344-353. http://dx.doi.org/10.1111/j.1365-2478.1976.tb00931.x

Heredia, O. S., \& Cirelli, A. F. (2007). Groundwater chemical pollution risk: assessment through a soil 
attenuation index. Environmental Geology, 53, 249-255.

IBGE - Brazilian Institute of Geography and Statistics. (2007). Cartographic Base. Brasília: IBGE.

IG - Geological Institute of the State of São Paulo, CETESB - Environmental Company of the State of São Paulo, \& DAEE - Department of Water and Electric Energy of the State of São Paulo. (1997). Vulnerability mapping and risk of groundwater pollution in the State of São Paulo. São Paulo: IG, DAEE, CETESB.

IPT - Institute for Technological Research of the State of São Paulo. (1977). Vertical electrical soundings: Datasheets and original field curves. São Paulo: IPT.

IPT - Institute for Technological Research of the State of São Paulo. (1978). Vertical electrical soundings: Datasheets and original field curves. São Paulo: IPT.

IPT - Institute for Technological Research of the State of São Paulo. (1980a). Vertical electrical soundings: Datasheets and original field curves, blocks 39, 44 and 45. São Paulo: IPT.

IPT - Institute for Technological Research of the State of São Paulo. (1980b). Vertical electrical soundings: Datasheets and original field curves. São Paulo: IPT.

IPT - Institute for Technological Research of the State of São Paulo. (1981). Vertical electrical soundings: Datasheets and original field curves, block 45. São Paulo: IPT.

Iritani, M. A., Ferreira, L. M. R., Fernandes, A. J., \& Ezaki, S. (2011). Strategic environmental project to aquifers: synthesis of activities in the period 2007 - 2010. São Paulo: IG, SMA.

Kearey, P., Brooks, M., \& Hill, I. (2002). An introduction to geophysical exploration. Malden, MA: Blackwell.

Landim, P. M. B. (2000). Introduction to spatial estimation methods for mapping. Retrieved August 12, 2013, from http://www.rc.unesp.br/igce/aplicada/DIDATICOS/LANDIM/interpo.pdf.

Maillet, R. (1947). The fundamental equations of electrical prospecting. Geophysics, 12(4), 529-556. http://dx.doi.org/10.1190/1.1437342.

Orellana, E. (1972). Geoelectrical survey by direct current. Madrid: Paraninfo.

Porsani, J. L., Carlos, I. M., Elis, V. R., \& Prado, R. L. (2012). Integrated geophysical methods for hydrogeological characterization of the aquifers in the microbasin Andes, Bebedouro, in the State of São Paulo. Brazilian Society of Geology, 43(3), 597-614.

Qamhieh, N. S. A. R. (2006). Assessment of groundwater vulnerability to contamination in the West Bank, Palestine (Unpublished master's thesis). An-Najah National University, Nablus, Palestine.

Telford, W. M., Geldart, L. P., \& Sheriff, R. E. (2004). Applied geophysics (2nd ed.). New York, NY: Cambrige University Press.

Van Duijvenbooden, W., \& Van Waegeningh, H. G. (1987). Vulnerability of soil and groundwater to pollutants, Proceedings and Information No. 38 of the International Conference held in The Netherlands. TNO Committee on Hydrological Research, Delft, The Netherlands.

Van Stempvoort, D., Ewert, L., \& Wassenaar, L. (1992). AVI: A method for groundwater protection mapping in the prairie provinces of Canada. Saskatoon: Groundwater and Contaminants Project, Environmental Sciences Division, National Hydrology Research Institute.

Varnier, C., Iritani, M. A., Viotti, M., Oda, G. H., \& Ferreira, L. M. R. (2010). Nitrate in groundwater in the Bauru Aquifer System, urban area of the Marilia municipality. Journal of the Geological Institute, 31(1-2), $1-21$.

Vrba, J., \& Zaporozec, A. (1994). Guidebook on mapping groundwater vulnerability. International Association of Hydrogeologists (IAH), 16, 31-48.

\section{Copyrights}

Copyright for this article is retained by the author(s), with first publication rights granted to the journal.

This is an open-access article distributed under the terms and conditions of the Creative Commons Attribution license (http://creativecommons.org/licenses/by/3.0/). 